\title{
Minorities in Iraqi Constitution: A Critical Analysis of the Legal Discourse
}

\author{
Kawa Abdulkareem Sherwani1 a, Dr. Abdullah Omar Yassen ${ }^{\mathrm{b}}$ and Ayad Yasin Husein Kokha ${ }^{\mathrm{c}}$ \\ A \\ Department of Media Techniques, Erbil Technical Administrative College, Erbil \\ Polytechnic University, Kurdistan region of Iraq \\ bepartment of Media Techniques, Erbil Technical Administrative College, Erbil \\ Polytechnic University, Kurdistan region of Iraq \\ ${ }^{\mathrm{C}}$ College of Law, University of Salahaddin-Erbil, Kurdistan region of Iraq
}

Article History: Received: 11 January 2021; Accepted: 27 February 2021; Published online: 5 April 2021

\begin{abstract}
Between 1979 and 2003, when Baath party was in power in Iraq, minorities were neglected and were not part of the decision-making process. It was the priority of the new government that other components of Iraq where part of the process. The draft of the constitution of 2005, in a number of provisions, do mention all the Iraqi components. However, no law has been passed to protect the rights of minorities and there is lack of appropriate mechanism to bring perpetrators to justice once violations have been committed against them. The data is taken from the English version of the Iraqi Constitution. The principles of critical discourse analysis areused as method to deconstruct the legal language of the constitution. This research undertakes a critical analysis of the legal discourseof the Iraqi Constitution and examines the provision of the constitution to highlight whether minorities in Iraq are protected under the constitution and whether the legal language of the constitutionis drafted in a way that is not vague or ambiguous to guarantee that protection. It is an attempt to investigate the legal language of Iraqi Constitution critically. The study concludes that the constitution was written in a way that may allow different interpretations, that is why it is difficult to be implemented with the available mechanisms. The study recommends that the constitution should be amended in a way that is inclusive of all minorities in Iraq and the provisions represent the quality between and among all the Iraqi components.
\end{abstract}

Keywords: Minorities; Iraqi Constitution;legal language; Critical Discourse Analysis.

\section{Introduction}

Historically, Mesopotamia (Iraq) is regarded as one of the first civilized centres in the world. As a consequence, it must be characterised as being enriched with diversity in the field of groups, customs, traditions, folklore, languages, religions, and subsequent empires inherited by contemporary Iraq since its establishment in the early 1920s. The country maintains various historical minorities; some of them may be more than 20 centuries old, such as Yezidis, Zoroastrians, Mandaeens-Sabian, etc. These minorities are divided into different racial, ethnic, linguistic, and religious groups. Occasionally, the Iraqi minority per se is divided into other smaller minorities within itself at the doctrinal or religious levels; e.g. the Christian minority. At other times, Iraq may have an exclusive minority worldwide, such as the Shabak minority, which is considered an Iraqi minority (Salloum, Protection of Religious, 2017, pp. 121-122).

For decades in Iraq, minorities have been undermined by subsequent governments and their basic rights have been violated. During successive governments, they have battled economic, social and political marginalisation (For in-depth analysis on the minority persons' rights and the infringement and abuse they suffered, see Sa'ad Salloum, Minorities in Iraq, 2013). However, after the former Iraqi Baathist Regime was overthrown by the US occupation forces in 2003; a new constitution containing federal, pluralistic, and democratic principles was issued in 2005 by a popular referendum. The preamble of this constitution reflects the long history of Iraqi society, respects human rights and fundamental freedoms, and promotes democracy, as well as preserving all Iraqi demographic components without any discrimination (Constitution of the Republic of Iraq, 2005).

Despite adopting new constitution,the minority groups are still not protected and they continue feel vulnerable within the country. The rise of ISIL in 2014,once again resulted in minorities suffering numerous human rights abuses and forcibly displaced. This furtherprovesthat the status of minorities to this day remain 'perilously unstable and perpetually under threat' in Iraq (Salloum, 2016).

The paper starts with a brief history of the Iraqi Constitution. Subsequently, it describes the most important theoretical notions on which it draws and the methodology it uses. The concept of minorities in international law will be explored to identify an appropriate definition for minorities going forward as there are different views among commentators on the exact definition of minority in international law. This is in part due to lack of universal meaning of the term. The paper then provides an analysis of key passages of the Constitution, i.e. passages most closely related to minorities, and discusses the repercussions the findings might have on the theory of discourse and ideology. The study also highlights a significant legislation adopted by Kurdistan Region Parliament explicitly on minority rights and the protection they should get. 
One has to applaud the successful governments post Saddam regime to include minority group members to the national governments, and become the members of legislature. The minority groups have also been given platform to actively and passively access local elections, and thus have a voice in city councils. Therefore, they are part of the political decision-making in the country. Having said that, to certain extent, minorities are more or less effectively excluded from more influential text and talk about their own position. Although they are frequent topics of political talk and text, thispassive access is hardly controlled by them: they have virtually no influence on this 'representation' in political discourse.

\section{Research Methodology}

This research uses mixed method of doctrinal research and Critical Discourse Analysis (CDA). The former is also known as documentary research, or 'black-letter' law research. To evaluate legal rules, this method makes comprehensive reference to international instruments, academic commentary, policy documents, and independent reports (Mike McConville \& Wing Hong Chui, 2007, pp. 3-4). CDA, recently, has been used quiet often to study text and talk. It emerged from Critical Linguistics (henceforth CL), critical semiotics and from a socio-politically conscious and appositional way of investigating language, discourse and communication. CDA attempts at uncovering of implicit ideologies in texts. As Widdowson (2007: 70) states, "those who follow this approach are particularly concerned with the use (and abuse) of language for the exercise of socio-political power (Sherwani, and Qaradakhy, 2019).

Many genres of political discourse, such as parliamentary debates, political speeches, laws, propagandas, etc., are largely defined in contextual, rather than in textual, terms. Political discourse is not primarily defined by topic or style, but rather by who speaks to whom, as what, on what occasion and with what goals, i.e., political discourse is especially political because of its functions in political process (Moheddin \& Sherwani, 2019).

One of the crucial tasks of CDA is to account for the relationships between discourse and social power. More specifically, such an analysis should describe and explain how power abuse is enacted, reproduced or legitimised by the text and talk of dominant groups or institutions. Within the framework of such an account of discursively mediated dominance and inequality, this approach focuses on an important dimension of such dominance, that is, patterns of access to discourse (Teun A. van Dijk, 2013, 84-104).

\section{The Importance of the Study}

The Constitution has been widely discussed both in scholarly literature and in the media; there have been hardly any critical linguistic analyses of the text itself. It is important to analyze the legal language of the text as the law is the central site of power and regulates all discourses. Combining a linguistic analysis of transitivity and a discourse analysis of intertextuality, this paper aims at showing precisely how the provisions of the Iraqi Constitution mention minorities. Thispaper highlights whether the existing law, including the constitution, appropriately protects the right of minorities and whether the legal language of the constitution drafted in a way that is not vague or ambiguous.

\section{Drafting History of the Iraqi Constitution}

The Iraqi constitution was drafted during the US occupation with the mixture of Iraqis and international legal experts who participated in the drafting process. The diversity of the drafters impacted the content. The constitution was adopted on 15th October 2005, replacing the 'Law for the Administration of the State'. The constitution drafting committee consisted of 71 individuals, of whom only five were drawn from minority communities. The drafting process was complicated due to the uncompromised positions adopted by the three largest ethno-religious blocks of population: the Sunni, Shi a, and Kurds. After lengthy three-way dialogue, the constitution signaled a compromise arrived at through political negotiation between representatives of the three groups. However, the constitution faced criticism for the involvement of political elites, largely exiled politicians who served the interest of West ideology (Castellino and Cavanaugh, 2013, 182-2254).

Although the constitution was seen as permanent document and it was approved by a popular vote through referendum, there was limited political participation of minority communities in the drafting process. There was significant emphasis placed on the three ethno-religious blocks of population to reach agreement on the expense of other minorities who felt largely neglected in the process. (Castellino and Cavanaugh, 2013, pp. 221-224) note that the constitution 'lacks protection measures for basic norms and freedoms, and has alarmingly vague or conflicting articles on civil society, autonomy, minority and women's rights, political freedoms, and the role of religion'. In addition, in a briefing paper, (Atalla, Careccia and Ramadan, 2005) have outlined a range of issues at stake in the development of the constitution that requires resolution. However, to date yet these issues have not been resolved.

\section{The Concept of Minorities in International Laws}

Despite lack of consensus among the literature on the explicit definition of minority, there aresome attempts to clarify the term from international legal point of view. For instance, (Francesco Capotorti, UN Doc E/CN.4/Sub.2/384/Rev.1, 1977), the special rapporteur of the UN Sub-Commission on Prevention of Discrimination and Protection of Minorities, has defined minorities as '[a] group numerically inferior to the rest of the population of a State, in a non-dominant position, whose members - being nationals of the State-possess ethnic, religious or linguistic characteristics differing from those of the rest of the population and show, if only implicitly, a sense of solidarity, directed towards preserving their culture, religion or language'.

(United Nations Declaration on the Rights Minorities, the General Assembly Resolution A/RES/47/135, 1992, Article 1(1), proclaims that 'States shall protect the existence and the national or ethnic, cultural, religious and linguistic identity of minorities within their respective territories and shall encourage conditions for the promotion 
of that identity'. More recently, (Mihandoost and BabajanianFatemeh and Bhman, 2016, p. 16)have defined 'A minority is a group of country's subjects that constitute a small proportion of population and do not participate in the country's government and have ethnic, religious, or lingual properties different from the majority of the society and there is some sort of feeling of unity that results from collective will for survival and they intend to achieve real and legal equality with the majority of people'.

It is common among the above-mentioned definitions that minorities are groups who are not part of the government and they are as a group are smaller than the rest of the society. They are minority based on their religion, ethnicity, language, culture, origin, and nationality. This group is the subject of this study and it has been defined in the broadest possible sense. This is because there is lack of universal definition of the term in international law.

\section{The Provisions of the Iraqi Constitution on Minorities}

The Iraqi Constitution has used the concept of 'component' instead of minority. In fact, the term 'minority' has only been mentioned in the constitution once. (Iraqi Constitution, 2005, Article 125) explicitly calls for the protection of minorities and fulfilment of their rights in various sectors. The Article prescribes that 'This constitution shall guarantee the administrative, political, cultural, and educational rights of the various nationalities, such as Turkmen, Chaldeans, Assyrians, and all other constituents, and this shall be regulated by law'. However, Iraq has yet to adopt a law to regulate the right of minorities. There are number of other provisions that the Iraqi constitution mentioned various minority groups and implied language that refers to this particular group. For example, (Iraqi Constitution, 2005, Article 2(2) denotes that the constitution will ensure "the full religious rights to freedom of religious belief and practice of all individuals such as Christians, Yezidis, and Mandean Sabeans'. (Iraqi Constitution, 2005, Article 3) lays down that 'Iraq is a country of multiple nationalities, religions, and sects'. (Iraqi Constitution, 2005, Article 7(1) obligates that 'any entity or program that adopts, incites, facilitates, glorifies, promotes, or justifies racism or terrorism... under any name whatsoever, shall be prohibited'.(Iraqi Constitution, 2005, Article 10) assures the sanctity of holy shrines, religious sites, and civilizational entities, guaranteeing the free practice of rituals in them. (Iraqi Constitution, 2005, Article 14)states that 'Iraqis are equal before the law without discrimination based on gender, race, ethnicity, nationality, origin, color, religion, sect, belief or opinion, or economic or social status'.

One of the most important provisions guaranteeing minorities protection is the text of (Iraqi Constitution, 2005, Article 37(2), which states 'The State shall guarantee protection of the individual from intellectual, political and religious coercion', and (Iraqi Constitution, 2005, Article 41), which reads 'Iraqis are free in their commitment to their personal status according to their religions, sects, beliefs, or choices, and this shall be regulated by law'; as well as (Iraqi Constitution, 2005, Article 43(1), which specifies that 'the followers of all religions and sects are free in... practice of religious rights... management of religious endowments (waqf), their affairs, and their religious institutions'. (Iraqi Constitution, 2005, Article 49(1) adds that 'the Council of Representatives shall consist of a number of members... The representation of all components of the people shall be upheld in it'.

The above analysis shows that in different places in the constitution the minority explicitly or various minority groups implicitly has been mentioned. This is done deliberately by the drafters to highlight the important status of minorities in new Iraq and the huge contribution they make to the political participation and enrichment of the community. However, the lack of explicit law to regulate guarantee the administrative, political, cultural, and educational rights of minorities left them in vulnerable position within the country. In fact, they have faced many discrimination and attacks by various government and terrorist groups (Salloum, 2016).

\section{Critical Analysis of Iraqi Constitution on Minorities}

This section critically analyses the provisions of the Constitution that is related to the minorities to evaluate the legal language and the presentation of the minorities in the constitution. The provisions of the Iraqi Constitution explicitly outline robust protection of minorities and guarantee their equal treatment irrespective of gender, race, ethnicity, origin, colour, religion, creed, belief or opinion, or economic or social status (Iraqi Constitution, 2005, Article 14). The Constitution, as a highest law on the land, sets forth strong guarantees and equal treatments of all Iraqis including minoritiesand this has set a precedent for the subsequent legal texts. Despite these solid provisions, there are number of Articles have left minorities in precarious position because of lack of implementation. For example, Article 2(1)(A) only allows legislations to be passed that does not contradict the established provisions of Islam law (Sharia Law). Therefore, any law that contradicts other religions that exist in Iraq is not void and it is allowed. This provision might hinder the legal provisions that provide legal protections to minorities. To include other religions also encourage the drafters to draft and propose legislations that improve the legal status of minorities and indorses many existing legal guarantees. The provision of Iraqi constitution and any other subsequent laws must protect all Iraqi components and other vulnerable groups from discrimination and afforded equal protection under Iraqi law.

In addition, Article 125 guarantees the rights of some groups of minorities such as Turkmen, Chaldeans, and Assyrians. However, other minority groups, such as Assyrians, Kakayis and Shabaks, do exist in Iraq and the language of the Constitution should not include some minority groups while exclude others. Instead, it should make a reference to all of Iraq's minorities. The legal language should be as general as possible to bring all 
minorities under one umbrella. Article 125 also calls for a law to regulate the rights owed to minorities. However, unlike KRI Parliament, such law does not exist in Iraq. The Parliament has yet to adopt such legislation that 'guarantee(s) the administrative, political, cultural, and educational rights of the minorities.

In respect of the preamble, the Constitution should reinforce the contribution of all minorities towards the modern Iraq. The minorities have strived for the development of democratic system in Iraq. The Constitution should highlight their contribution to cultural and political heritage in the country.The Constitution is a step forward in comparison to previous laws and constitutions in respect of prohibiting the ownership of land for the purpose of changing demography both within and between governorates. Article 23(3)(b) explicitly notes that 'ownership or property for the purpose of demographic change is prohibited'. This was not the case under previous regime. The Baath party practiced forced displacement to achieve 'Arabization' in the areas where Arab was minority in that region.

Article 9(1)(a) notes that all 'the Iraqi armed forces and security services will be composed of the components of the Iraqi people with due consideration given to their balance and representation without discrimination or exclusion'. To regulate the implementation of this equality of the equal representation, Article 9(2) stipulates that 'military service shall be regulated by law'. However, so far, such law does not exist to ensure the full implementation of such equality.

Article 14 of the Constitution replicates the provisions of the International Covenant on Civil and Political Rights in making reference to equality before the law. However, the provision should make reference to 'language' as one of the bases for discrimination,Article 41 'Iraqis are free in their commitment to their personal status according to their religions, secs, believes or choices'. This provision, once again, obligates that it should be regulated by law. However, such law has not yet been adopted. The provision should also mention 'the needs of non-Muslim minorities'. According to Article 49 (1), the representation of minorities in the Council of Representatives is based on quota system, meaning that a ratio of one representative per 100,000 Iraqis is selected to become a member in the Council. However, this system is subject of criticism. The critics note that if a quota system based on the percentages of minorities in the population is suggested [in the Constitution], the proposed amendment should ensure that the goal of such a system would be not to appoint token officeholders, but to include, engage, represent and empower all components of Iraqi society' Institute for International Law and Human Rights (Minorities and the Law in Iraq).

\section{Minorities in Kurdistan Region of Iraq}

Aftermath of ISIL systematic attacks against minoritiesin 2014, and with a view to protect this group from further discriminative attacks, Parliament of Kurdistan Region of Iraq passed a 'Law of Protecting the Rights of Components in Kurdistan - Iraq' (Law of Protecting the Rights of Components in Kurdistan, No. 5 of 2015). The provisions of this law reflect the provisions of the (United Nations Declaration on the Rights Minorities, the General Assembly Resolution A/RES/47/135, 1992, Article 1(1), calling on states to 'adopt appropriate legislative and other measures' to 'protect the existence and the national or ethnic, cultural, religious and linguistic identity of minorities'. This is exactly what the Kurdistan Parliament has done. Article three endorses that the Kurdistan Regional Government (KRG) will guarantee efficient and full equality to components in all political, cultural, social, and economic aspects through the authority's policy for all members of any components, and allow them to participate in all other decisions effectively, without any type of discrimination against them, and that any violators of the policy will be punished by the applicable penal code. It also aims to prevent any religious, political, or media speech individually or collectively that brings hatred, exclusion, or marginalisation based on racial claims. The KRG will confront any policy that changes the lives of indigenous people in related areas if it aims at replacing a demography or distorting historical and cultural heritages under any justification or for any reason. The law, in Article 4, further notes that all individuals are free to reveal their religious identity, and their rights are protected as a member of any specific community. Article 5 stipulates that 'components have group, organization, components' representation, intellectual, learning and social and development relations with those who have ethnic, religious and national commons inside or outside the Kurdistan Region based on the applicable laws, and in case when the governments signs international or regional protocols related to components, their participation will be guaranteed'; moreover, Article 6 sets out 'to guarantee the rights of components: First they have the right to participate in executive and legislative authorities based on the applicable laws. Second: in places which are inhabited by components, they have the right to participate in governing governmental and administrative institutions, based on the applicable laws'.

The provisions of this law fully protect the rights of minority groups and guarantees their participation in the decision making and political process in the region. The law replicates the provisions of Declaration on minority rights and international human rights standards on the protection of minority groups. As noted above, such legislation does not exist in Iraq and this has contributed to lack of participation of minority groups in the governing bodies in the State.

\section{Conclusion}

Throughout history and in various parts of the world, minorities have been subjected to discriminative attacks. This phenomenon is clear to be witnessed in Iraq history. Although the latest constitution of Iraq makes explicit reference to various minority groups and highlights the positive existence of minorities in Iraq, they have not prevented the committing of violence acts against those vulnerable groups in the state, one of the most ancient civilizations worldwide. The constitution guarantees the rights of some groups, but does not mention some others; 
the language of the constitution should not include some minority groups while exclude others. Instead it should make a reference to all of Iraq's minorities. The legal language should be as general as possible to bring all minorities under one umbrella.Therefore, Iraqi Constitution, as the highest legal text in the country, requires amendments because, as it stands, the Constitution contains loopholes pertaining to practical application and executive mechanisms to guarantee the protection and preservation of such minorities' rights, primarily, the noninclusion of criminal sanctions against perpetrators. However, if Iraqi Constitution does not make necessary amendments, it will remain wishful thinking in the form of symbolic formulations solely advocating for democracy and the protection of human and minorities' rights and fundamental freedoms, without implementation. However, if amendment is not achieved, then implementation of certain provisions is necessary.

\section{References}

A. Books and Journals:

1. Kokha, 'ISIL's Genocide of Iraqi Minorities: A Study in International Criminal Law' (The research is under publication, 2019).

2. F. Capotorti, Special Rapporteur, Study on the Rights of Persons Belonging to Ethnic, Religious and Linguistic Minorities, UN Doc E/CN.4/Sub.2/384/Rev.1 (1977).

3. F. Mihandoost and B. Babajanian, The Rights of Minorities in International Law, Journal of Politics and Law, Vol. 9, No. 6; 2016

4. J. Castellino and K. Cavanaugh, Minority Rights in the Middle East, Oxford University Press, 2013, pp. 221-224.

5. Joshua Castellino and Kathleen A. Cavanaugh, 'Minority Rights in Iraq' in J. Castellino \& K. Cavanaugh (eds), Minority Rights in the Middle East (Oxford University Press, 2013).

6. M.McConvilleand W. H.Chui Introduction and Overview' in Mike McConville and Wing Hong Chui (eds) Research Methods for Law(Edinburgh: Edinburgh University Press2007).

7. Moheddin, K. R., \& Sherwani, K. A. (2019). Hedges used in Kurdish Political Discourse. International Journal of Psychosocial Rehabilitation, 23(03), 648-657.

8. N. Atalla, G. Careccia and A. Ramadan, CAABU Briefing: The New Constitution of Iraq (Council for the Advancement of Arab-British Understanding (CAABU) No. 84 August 2005).

9. Sherwani, K. A., \& Qaradakhy, B. H. (2019). Critical Analysis of the Political Media Disc ourse of “ Haide r Al- Abbadi " the Former Iraqi Prime Minister. International Journal of Psychosocial Rehabilitation, 23(03), 595-601.

10. S. Salloum, Protection of Religious, Ethnic and Linguistic Minorities in Iraq: Analytical Study in International: Regional and National Frameworks, in Arabic (Iraqi Al-Amal Association, 2017).

11. S. Salloum, At Crossroads: Iraqi Minorities After ISIS (Library of Minority Rights, 2016).

12. S. Salloum, Minorities in Iraq: Memory, Identity and Challenges (Masarat for Cultural and Media development, 2013).

13. S. K. Määttä, 'The Foundations of Europe: A Critical Discourse Analysis of the EU Constitution' 1(1) Critical Approaches to Discourse Analysis Across Disciplines166-178

14. T. A. Van Dijk, 'Discourse, Power and Access' in Carmen Rosa Caldas-Coulthard, Malcolm Coulthard (eds) Texts and Practices: Readings in Critical Discourse Analysis (2013) 84-104.

15. T. A.Van Dijk, Elite Discourse and Racism (Newbury Park, CA: Sage1993)

16. Legislations:

17. Constituting Democracy in Iraq: ChaloAssyrians a Determinant of Sustainable Iraqi Constitutionalism (August 2005) http://www.iraqdemocracyproject.org/pdf/ConstitutingDemocracyinIraq.pdf

18. Declaration on the Rights of Persons Belonging to National or Ethnic, Religious and Linguistic Minorities. Adopted by the GA resolution (A/RES/47/135), New York on 18/12/1992.

19. Law of Protecting the Rights of Components in Kurdistan - Iraq No. 5 of 2015, No. 5 of 2015, Kurdistan Parliament Publications, Erbil, 2015.

20. Reports:

21. Institute for International Law and Human Rights, 'Minorities and the Law in Iraq: Executive Summary' http://iilhr.org/exsummaryen.pdf

22. Iraqi Interim Government, 'Announcement Ceremony: Press Packet' 16. Available at: https://govinfo.library.unt.edu/cpa-iraq/government/press_packet.pdf

23. S. Mathieu-Comtois, 'Reporting on Minorities across Iraq in Arabic \& Kurdish Press' (the Institute of Regional and International Studies (IRIS) at the American University of Iraq, Sulaimani (AUIS), April 2016).Available https://auis.edu.krd/iris/sites/default/files/Minorities\%20and\%20the\%20Media\%20in\%20Iraq_IRIS.pdf

24. P. Taneja, 'Iraq's Minorities: Participation in Public Life' (Minority Rights Group International Report, 2011). Available at: https://www.refworld.org/pdfid/4ed612bc2.pdf 